\title{
Investigation of Pedagogical Content Knowledge of Turkish Foreign Language Teacher Candidates Oriented Instructional Strategies ${ }^{i}$
}

\author{
Murat Aydın",*, Fatma Açık ${ }^{2}$ \\ ${ }^{1}$ Faculty of Education, Amasya University, Amasya, Turkey \\ ${ }^{2}$ Gazi Faculty of Education, Gazi University, Ankara, Turkey
}

Copyright $\bigcirc 2018$ by authors, all rights reserved. Authors agree that this article remains permanently open access under the terms of the Creative Commons Attribution License 4.0 International License

\begin{abstract}
The aim of this study is to determine the pedagogical content knowledge of Turkish teacher candidates for instructional strategies while teaching Turkish as a foreign language. One of the theories that are based on educating prospective teachers in a qualified and equipped manner is pedagogical content knowledge. In this study, the instructional strategies that one of the pedagogical content knowledge components and the pedagogical content knowledge of the teacher candidates were examined and how much they can apply the information, methods, techniques and strategies they have. The sample of this research, which is one of the qualitative research methods, consists of 47 senior class teacher candidates in Amasya University Turkish Language Department. In the study "Teaching Turkish as a Foreign Language Instructional Strategies Knowledge Test" was used as a data collection tool that developed by the researcher. Knowledge test consisting of six open-ended questions for cognitive process steps and the implementation step; a total of six experts, including four field experts and two assessment experts were consulted. The data of the study was carried out by descriptive analysis method to evaluate pedagogical content knowledge. According to the results of the study, it was determined that the teacher candidates have not difficulty in the questions about determining the teaching methods, techniques and student errors. However, they have difficulty in the applications to eliminate student errors.
\end{abstract}

Keywords Instructional Strategies, Teaching Turkish as a Foreign Language, Teacher Candidates, Pedagogical Content Knowledge

\section{Introduction}

In the light of the scientific, cultural and political developments in the world in recent years, a large number of papers on the teaching of Turkish as a foreign language has been presented, the thesis has been prepared, articles and books have been written. These studies revealed the deficient and the needs in the field of teaching Turkish as a foreign language; experienced instructor, material, curriculum. In order to meet these needs, textbooks and teaching materials were prepared, Turkish language teaching centers and Turkish language teaching certificate programs to foreigners were opened.

One of the most important issues to be addressed in teaching Turkish as a foreign language is to train qualified teachers. Teachers are one of the most important elements of the education system, which will raise individuals to meet the needs of societies [1]. One of the basic building blocks of the education system consists of two basic structures: teaching professional and personal characteristics [2]. A qualified teacher in terms of professional competence; have a high level of knowledge and skills in the fields of general culture, subject content knowledge and teaching profession knowledge [2-4]. Many teachers have tried to find answers to questions such as; How do I better explain the basic concepts to my students? Which materials should I use? How can I best evaluate them? What challenges will my students face in the learning process? [5]. One of the models developed on the teacher's professional knowledge development in order to find answers to these questions is the concept of pedagogical content knowledge put forward by Shulman [6]. Shulman [6] developed a model that integrates these two types of knowledge rather than mentioning the knowledge of pedagogy and content knowledge separately. This new type of knowledge is called "pedagogical content knowledge" [7]. The most important element of pedagogical content knowledge is that it separates a teacher and a field specialist. Hereby, the teacher differs not only from the quality and quantity of the information he has from a literary, physicist, biologist, chemist or 
mathematician but also from the point of organizing and using the information [8]. Today, there are some discussions about the importance of teacher knowledge and how teacher knowledge is built [9]. The initial definitions of teachers' knowledge structures have often emphasized on the sufficient knowledge of the field. At present, teacher-training institutions carry out their education in two basic fields: field knowledge and pedagogy. De Jong and Ferguson-Hessler [10] argued that knowledge is central to research in learning and teaching. A person's knowledge base has been accepted as a general requirement for the creation of other types of information. They stated that they have different characteristics such as the style of knowledge, the level of effectiveness of knowledge, and the generality of knowledge. Recently, teachers' dimensions of identifiable teacher knowledge have been demonstrated to change the unsuccessful appearance of teacher education. These efforts are often expressed in terms such as teacher qualifications, quality, or dimensions and standards of instruction [11]. Professional knowledge of teachers is discussed as a prerequisite for successful teaching. Professional knowledge includes attempts to clearly or explicitly identify the quality of education [12]. The concept of professional knowledge during teacher education implies all kinds of theoretical knowledge, as well as the work of in-service teachers and the skills of the systematic study of teaching exercises [13]. The general belief in pedagogic content knowledge is that teachers have the ability to organize the best ways of understanding the content of a particular subject [14]. This knowledge is to know which teaching approaches fit the content, and also to know which elements of the content can be adapted for better teaching. Pedagogic content knowledge deals with the representation and formulation of concepts, pedagogical techniques, knowledge of concepts, knowledge of what makes it easy or difficult, and theories of knowledge philosophy. In addition, it includes knowledge of the pre-knowledge that students bring to learning practices and knowledge of appropriate teaching representations to address conceptual errors [15]. PCK forms a specific form of teacher professional knowledge. It also refers to the transformation of subject area knowledge within certain forms. The PCK enables the communication process between the teacher and the student to be effective and flexible [16]. Three factors contributed to the development of PCK in the teacher career; the first one is to have qualified subject area knowledge, the second is a class experience and the third is a good level of personal self-confidence [17]. The PCK structure is a pedagogical structure that the teacher develops as a result of the reflection of the subjects in the teaching as well as the repetition of teaching and planning [9]. In other words, the emerging model makes a new definition and a more specialized profession. One of the sub-components of the pedagogical content knowledge in this study is the knowledge of instructional strategies to reveal the teaching methods and techniques of the teacher, to eliminate the misconceptions and mistakes made by the students and to transfer the knowledge and skills of the teacher about their teaching strategies to their students. In the literature, there are several studies on pedagogical content knowledge and teaching Turkish. One of the studies conducted on the use of pedagogical content knowledge in Turkish teaching is Batur and Balc1's [18] study that investigation of pedagogical content knowledge of Turkish teacher candidates. This study was conducted to determine the pedagogical content knowledge of Turkish teacher candidates. The research was conducted with the participation of five Turkish teacher candidates in the fall semester of 2012-2013, and semi-structured interview form was used as data collection tool. Within the scope of the study, the curriculum information, subject content knowledge, teaching information and measurement-evaluation knowledge of the Turkish teacher candidates were analyzed in accordance with the pedagogical content components. According to the findings, it was find out that teacher candidates' knowledge of the curriculum and the subject content were incomplete and that the traditional approaches to teaching information still persist. Although many studies have been done in different disciplines related to pedagogical content knowledge in literature, very few studies has been found in Turkish language teaching and no study in teaching Turkish as a foreign language. This study is noteworthy in terms of adding a new breath to the field of teaching Turkish as a foreign language.

\subsection{Purpose of the Study}

The aim of this study is to determine the pedagogical content knowledge of instructional strategies for Turkish teacher candidates and to determine the level of knowledge they can use in teaching Turkish as a foreign language. In line with this aim, questions related to the comprehension and application step in the upper levels of the cognitive level, such as identifying student errors, identifying mistakes, and identifying which methods and techniques will be used for a given educational situation were prepared. With this knowledge test, the knowledge, teaching methods and techniques of teacher candidates and their pedagogical knowledge have been determined.

\section{Materials and Methods}

The method of this study is the descriptive survey model, which is one of the qualitative research methods. The survey model is a research method that aims to describe a situation that exists in the past or the present. [19]. The target population of study consists of 47 Turkish teacher candidates. The data of the study were collected 
through the Teaching Turkish as a Foreign Language Instructional Strategies Knowledge Test, which consists of six open-ended questions developed by the researcher. The knowledge test, which was prepared to measure the pedagogical content knowledge of the trainee teachers for instructional strategies, was examined by four field experts and two measurement and evaluation experts and no problem was observed in performing the test. The first question of this knowledge test was to determine the errors of grammar and syntax of foreign students, to determine the cause of the errors and to find the appropriate methods and techniques to correct the errors. The second question is to determine the teacher candidate's strategy of using images, and the third is the method and technique of teaching Turkish as a foreign language at the basic, intermediate and advanced levels. In the fourth question, how to choose one of the cultural elements and how to teach them according to the levels, in the fifth question, is to determine the mistakes and reasons of the foreign students in the writing examination and to find the appropriate teaching methods and techniques to solve the errors. The last question of the knowledge test is the question of the pedagogical content knowledge in order to determine which country the candidate wants to go to teach Turkish as a foreign language and which teaching methods and techniques will be used to teach the specific features of this country. Descriptive analysis method was used to analyze pedagogical content knowledge. In this context, the question of the data obtained from the information test was taken into consideration and comments were made about the answers.

\section{Findings}

The findings of the study consist of descriptive analyzes of these answers and their answers to the Teaching Turkish as a Foreign Language Instructional Strategies Knowledge Test.

The first question of the knowledge test consists of the answers given by the international students who learned Turkish as a foreign language in the written exam. Teacher candidates were asked about the errors they had made, the reasons for making these mistakes and the methods and techniques, which should be used to eliminate the errors. The first question of the instructional strategies knowledge test is as follows;

"1. What are the mistakes students make in the following sentences? Why do you think students have made these mistakes? Explain which method, technique and strategy you use to resolve these errors.

"I live Amasya."

"I came Kyrgyzstan."

"I love turkey."

"My brother lives Ankara."
The answers of prospective teachers are shown in the table below.

Table 1. Student errors, causes and methods, techniques

\begin{tabular}{|l|l|}
\hline Question Content & Frequency \\
\hline Student errors & 46 \\
\hline Punctuation error & 40 \\
\hline Using incorrect suffix & 41 \\
\hline Conjunction error & 35 \\
\hline Causes of error & 9 \\
\hline Lack of subject & 3 \\
\hline Unknow structure of Turkish & 3 \\
\hline Unknow suffix & 3 \\
\hline Unknow punctuation & 2 \\
\hline Lack of speaking practice & 1 \\
\hline Methods and techniques & 39 \\
\hline Discovery learning strategy & 12 \\
\hline Drama & 12 \\
\hline Question-answer & 11 \\
\hline Expression & 11 \\
\hline Performing & 10 \\
\hline Discussion & 9 \\
\hline Station & 9 \\
\hline Educational games & 8 \\
\hline Project & 7 \\
\hline Binary audit & 6 \\
\hline Role playing & 5 \\
\hline Demonstration & 3 \\
\hline Speech ring & 2 \\
\hline Inclusion & 1 \\
\hline
\end{tabular}

As far as we can see from Table 1, all but one of the teacher candidates identified the mistakes made by the students. In addition, only nine pre-service teachers were able to answer the reasons for the errors. In terms of methods and techniques that can be used to correct the errors, which are the last part of this problem, only seven students who wrote different methods and techniques did not specify any technical methods.

The second question of the knowledge test is the question of the cognitive level prepared to measure the strategies of using teacher imagination. Two images have been given to prospective teachers and an answer has been sought to determine how these images can be taught at the basic, intermediate and advanced levels of teaching Turkish as a foreign language. They were also asked to create an image themselves. The question is:

"2. The images given below have a number of image values. Write down your predictions about how these images can express Turkish as a foreign language according to their language level. Also, make a drawing of the empty box on the right that you think you have an 
image value. Indicate how this image will be explained according to language levels.
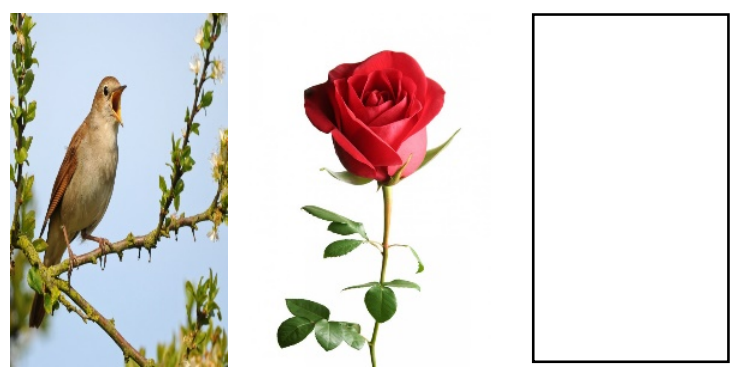

Basic level:

Intermediate level:

Advanced level:

The answers given to the second question of the knowledge test prepared for teacher candidates' strategy of using the image are given below.

Table 2. Image use strategy

\begin{tabular}{|l|l|l|}
\hline Images & Frequency & Percentage \\
\hline $\mathbf{1}^{\text {st }}$ Image (Basic level) & $\mathbf{4 2}$ & $\mathbf{8 9 \%}$ \\
\hline Bird & 23 & $54 \%$ \\
\hline Animal & 8 & $19 \%$ \\
\hline Cik cik & 4 & $9 \%$ \\
\hline Nightingale & 4 & $9 \%$ \\
\hline Sound & 2 & $4 \%$ \\
\hline Photograph & 1 & $2 \%$ \\
\hline $\mathbf{2}^{\text {nd }}$ Image (Basic level) & $\mathbf{4 2}$ & $\mathbf{8 9 \%}$ \\
\hline Flower & 24 & $57 \%$ \\
\hline Plant & 8 & $19 \%$ \\
\hline Rose & 7 & $16 \%$ \\
\hline Thorn & 3 & $7 \%$ \\
\hline $\mathbf{3}^{\text {rd }}$ Image (Basic level) & $\mathbf{3 1}$ & $\mathbf{6 6 \%}$ \\
\hline Flag & 5 & $16 \%$ \\
\hline Tree & 3 & $9 \%$ \\
\hline Pen & 3 & $9 \%$ \\
\hline House & 3 & $9 \%$ \\
\hline Night & 2 & $6 \%$ \\
\hline Drink & 2 & $6 \%$ \\
\hline Cocoon & 1 & $3 \%$ \\
\hline Autumn & 1 & $3 \%$ \\
\hline Light & 1 & $3 \%$ \\
\hline Dance & 1 & $3 \%$ \\
\hline City & 1 & $3 \%$ \\
\hline Star & 1 & $3 \%$ \\
\hline Olive branch & 1 & $3 \%$ \\
\hline Human & 1 & $3 \%$ \\
\hline Cotton & 1 & $3 \%$ \\
\hline Wood & 1 & $3 \%$ \\
\hline & & \\
\hline & 2 & \\
\hline
\end{tabular}

As seen in Table 2, prospective teachers have a success rate of $89 \%$ in naming the images given in terms of image utilization strategy and $66 \%$ in forming their own images. The first image is named in six different ways, while in the second image this number has fallen to four. Besides, the diversity of creating their own images is higher than the images given. With this question, teacher candidates created 16 different images and showed that they would use these images as Turkish as a foreign language. Among the images created, "flag" is the largest number. Although there are different images, $66 \%$ of the participants form their own image. One of the three students did not create their own image.

The third question of the instructional strategies knowledge test is a question type that takes place in the implementation step of the cognitive level. A total of three teaching conditions were given to the prospective teachers at the basic, intermediate and advanced levels and they were asked together with the reasons for which teacher techniques could be used. The third question of the knowledge test is as follows;

"3. Explain which teaching techniques you choose and explain why.

Level: Basic

Situation: The student introduces himself/herself first in the target language and then he meets his friends

Teaching Techniques:

Explanation:

Level: Intermediate

Situation: To understand tales and short stories in the target language

Teaching Techniques:

Explanation:

Level: Advanced

Situation: Student's specific linguistic products in the target language

Teaching Techniques:

Explanation:

The findings of the third question are given in the table below. 
Table 3. Instructional techniques according to teaching statues

\begin{tabular}{|c|c|c|c|}
\hline Level & Teaching Technique & Frequency & Percentage \\
\hline \multirow[t]{9}{*}{ Basic } & Drama & 8 & $18 \%$ \\
\hline & Expression & 6 & $13 \%$ \\
\hline & Question-answer & 5 & $11 \%$ \\
\hline & Demonstration & 4 & $9 \%$ \\
\hline & Aquarium & 4 & $9 \%$ \\
\hline & Speech ring & 3 & $7 \%$ \\
\hline & Buzz group & 2 & $5 \%$ \\
\hline & Who am I? & 2 & $5 \%$ \\
\hline & Inclusion & 2 & $5 \%$ \\
\hline \multirow[t]{7}{*}{ Level } & Teaching Technique & Frequency & Percentage \\
\hline & Educational game & 2 & $5 \%$ \\
\hline & Destiny & 1 & $2 \%$ \\
\hline & Thought chair & 1 & $2 \%$ \\
\hline & Binary audit & 1 & $2 \%$ \\
\hline & Role playing & 1 & $2 \%$ \\
\hline & Circle & 1 & $2 \%$ \\
\hline \multirow[t]{17}{*}{ Intermediate } & Drama & 11 & $26 \%$ \\
\hline & Role playing & 5 & $12 \%$ \\
\hline & Station & 4 & $10 \%$ \\
\hline & Expression & 3 & $7 \%$ \\
\hline & Photo frame & 2 & $5 \%$ \\
\hline & Hot chair & 2 & $5 \%$ \\
\hline & $\begin{array}{c}\text { Reading by taking } \\
\text { notes }\end{array}$ & 2 & $5 \%$ \\
\hline & Creative writing & 2 & $5 \%$ \\
\hline & Sing my bird sing & 1 & $2 \%$ \\
\hline & Gossip & 1 & $2 \%$ \\
\hline & Six hats & 1 & $2 \%$ \\
\hline & Aquarium & 1 & $2 \%$ \\
\hline & Fishbone & 1 & $2 \%$ \\
\hline & Deformation & 1 & $2 \%$ \\
\hline & Dictionary study & 1 & $2 \%$ \\
\hline & Performing & 1 & $2 \%$ \\
\hline & Listening & 1 & $2 \%$ \\
\hline \multirow[t]{14}{*}{ Advanced } & Creative writing & 19 & $49 \%$ \\
\hline & Station & 6 & $15 \%$ \\
\hline & Drama & 3 & $8 \%$ \\
\hline & Aquarium & 2 & $5 \%$ \\
\hline & Discussion & 1 & $3 \%$ \\
\hline & What it has game & 1 & $3 \%$ \\
\hline & Completion & 1 & $3 \%$ \\
\hline & Bring you end & 1 & $3 \%$ \\
\hline & Case study & 1 & $3 \%$ \\
\hline & Analogy & 1 & $3 \%$ \\
\hline & Bazaar & 1 & $3 \%$ \\
\hline & Guided writing & 1 & $3 \%$ \\
\hline & Project & 1 & $3 \%$ \\
\hline & Role playing & 1 & $3 \%$ \\
\hline
\end{tabular}

In Table 3, there were fifteen different teaching techniques at the basic level when the findings of the prospective teachers were able to use appropriate teaching techniques. The trainee teachers preferred the drama technique mostly from these techniques. The feature that draws attention at this level is that the techniques such as narration, question-answer, demonstration, etc. are preferred to a certain extent. As in the basic level for medium level education, drama technique is the leading one with a rate of $26 \%$ followed by role playing and station techniques. At this level, participants can use different techniques as they use basic level. When we come to the advanced level, the teaching technique which the teacher candidates want to use with a rate of $49 \%$ is the creative writing technique. This technique is followed by station and drama technique and a total of fourteen different teaching techniques have been used at this level. In the last part of this question, $86 \%$ of the teacher candidates stated the reasons for using the teaching technique.

The fourth question of the knowledge test is about the cultural element that can be used when teaching Turkish as a foreign language. The teacher candidates were given six visuals of Turkish culture in this question and they were asked to choose one of them and to teach them the methods and techniques they choose according to their language level. This question, which is directed towards both the cognitive level and the application level, is as follows;

"4. How would you use one of the cultural elements you choose from the following visuals for the basic, intermediate and advanced level in teaching Turkish as a foreign language? Which teaching methods, techniques and strategies will you benefit from for each level?
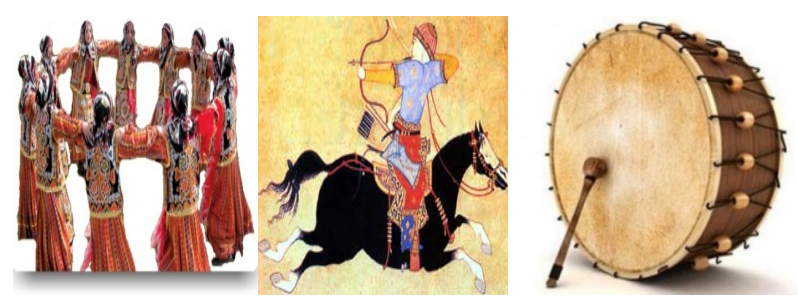

The findings of the fourth question of the knowledge test are given in the table below.

Table 4. Cultural Elements

\begin{tabular}{|c|c|c|}
\hline $\begin{array}{c}\text { Cultural } \\
\text { Element }\end{array}$ & Instructional Technique & Frequency \\
\hline Turkish Coffee & Demonstration & 4 \\
\hline & Drama & 3 \\
\hline & Question-answer & 3 \\
\hline & Expression & 2 \\
\hline & Performing & 2 \\
\hline & Aquarium & 2 \\
\hline & Short films & 1 \\
\hline & Panel & 1 \\
\hline & Speech ring & 1 \\
\hline & Buzz group & 1 \\
\hline
\end{tabular}




\begin{tabular}{|c|c|c|}
\hline Total & & 20 \\
\hline \multirow[t]{14}{*}{ Asşı Veysel } & Drama & 8 \\
\hline & Expression & 4 \\
\hline & Performing & 4 \\
\hline & Brainstorm & 2 \\
\hline & Demonstration & 2 \\
\hline & Role playing & 1 \\
\hline & Panel & 1 \\
\hline & Debate & 1 \\
\hline & Listening & 1 \\
\hline & What it has game & 1 \\
\hline & Station & 1 \\
\hline & Analogy & 1 \\
\hline & Research & 1 \\
\hline & Hot chair & 1 \\
\hline Total & & 29 \\
\hline \multirow[t]{2}{*}{ Archery } & Performing & 1 \\
\hline & Discussion & 1 \\
\hline Total & & 2 \\
\hline \multirow[t]{13}{*}{ Nasreddin Hodja } & Drama & 6 \\
\hline & Discovery learning strategy & 3 \\
\hline & Performing & 1 \\
\hline & Adumbration & 1 \\
\hline & Sense-making & 1 \\
\hline & Role playing & 1 \\
\hline & Expression & 1 \\
\hline & Question-answer & 1 \\
\hline & Creative writing & 1 \\
\hline & Brainstorm & 1 \\
\hline & Case study & 1 \\
\hline & Demonstration & 1 \\
\hline & Problem solving & 1 \\
\hline Total & & 20 \\
\hline \multirow[t]{14}{*}{ Folk Dances } & Demonstration & 8 \\
\hline & Drama & 4 \\
\hline & Video track & 3 \\
\hline & Expository teaching & 2 \\
\hline & Performing & 2 \\
\hline & Expression & 2 \\
\hline & Speech ring & 1 \\
\hline & Discussion & 1 \\
\hline & Cognitive traineeship & 1 \\
\hline & Perceiving & 1 \\
\hline & Discovery learning strategy & 1 \\
\hline & Research & 1 \\
\hline & Creative writing & 1 \\
\hline & Natural method & 1 \\
\hline Total & & 29 \\
\hline \multirow[t]{5}{*}{ Drum } & Audio-visual method & 2 \\
\hline & Demonstration & 1 \\
\hline & Video track & 1 \\
\hline & Role playing & 1 \\
\hline & Natural method & 1 \\
\hline Total & & 6 \\
\hline
\end{tabular}

As it is seen in Table 4, the most used cultural elements of teacher candidates are 29 folklore methods and techniques, together with Âşı Veysel. While demonstrating the technique of demonstration of folk dances, drama technique is the most used teaching technique in the teaching of Âşık Veysel and reed cultural element. Turkish coffee and Nasreddin Hodja share the second place with 20 teaching techniques in the distribution of the cultural elements that pre-service teachers prefer to teach. In these cultural elements, drama and showing and making techniques are the leading ones. Another unsure drum is six instructional techniques and archery is preferred by teacher candidates with only two teaching techniques.

The fifth question of the knowledge test is a question prepared for the level of comprehension which consists of the syntactic and linguistic errors of foreign students in a way similar to the first question. The students were asked about the mistakes they made, the reasons for making these mistakes and the methods and techniques which should be used in order to eliminate the errors. The question is:

"5. What are the mistakes students make in the following sentences? Why do you think students have made these mistakes? Explain which method, technique and strategy you use to resolve these errors.

"We will disturb friend home.":

"I want done to get it.":

"We don't see a good life there.":

"I will went in his direction and help me."

The participants' answers to the fifth question of the knowledge test are shown in the table below.

Table 5. Linguistic errors, causes, methods and techniques

\begin{tabular}{|c|c|c|}
\hline Question content & Frequency & Percentage \\
\hline Student's error & 42 & $89 \%$ \\
\hline Reasons of error & 11 & $23 \%$ \\
\hline Methods and techniques & 34 & $72 \%$ \\
\hline
\end{tabular}

As seen in Table 5, except five of the teacher candidates, all of the students determined the mistakes they made. In addition, only 11 pre-service teachers were able to answer the reasons of the errors. In terms of methods and techniques that can be used to correct the errors, which are the last part of this problem, 34 students wrote different methods and techniques. The rate of finding the causes of the error in this question has shown an increase compared to the first question. It was observed that pre-service teachers were more successful in identifying student errors and presenting teaching methods and techniques to correct errors.

The sixth and the last question of the knowledge test was prepared in order to determine which country teacher candidates would like to go to teach Turkish as a foreign language and which teaching method and technique to teach a cultural characteristic of this country. The question in the test is given below, the table reflects the findings. 
" 6 . Which country would you like to go to teach Turkish to foreigners? Write a cultural feature of this country that you want to go to. Explain which method, technique and strategy you use when teaching this cultural feature in the target language.

Table 6. Country and property

\begin{tabular}{|c|c|c|c|}
\hline Country & Property & Technique & Frequency \\
\hline South Korea & + & + & 5 \\
\hline Mongolia & + & + & 3 \\
\hline USA & + & + & 3 \\
\hline Bosnia and Herzegovina & + & + & 2 \\
\hline France & + & + & 2 \\
\hline Finland & + & + & 2 \\
\hline Japan & + & + & 2 \\
\hline Greenland & + & + & 2 \\
\hline Azerbaijan & + & - & 2 \\
\hline Turkmenistan & + & + & 2 \\
\hline China & + & + & 2 \\
\hline Germany & + & - & 2 \\
\hline Kirghizstan & - & + & 1 \\
\hline Algeria & + & + & 1 \\
\hline Australia & + & + & 1 \\
\hline India & + & + & 1 \\
\hline South Africa & + & + & 1 \\
\hline Iran & + & + & 1 \\
\hline Italia & + & - & 1 \\
\hline Uzbekistan & + & + & 1 \\
\hline Afghanistan & + & - & 1 \\
\hline Thailand & - & + & 1 \\
\hline Russia & + & - & 1 \\
\hline Kazakhstan & + & - & 1 \\
\hline England & + & + & 1 \\
\hline
\end{tabular}

As can be seen in Table 6, a large number of different countries where teacher candidates wanted to go to teach Turkish were identified. South Korea is the country the teacher wants to go to most. When we look at the most preferred countries, pre-service teachers indicated both the characteristics of the country and the methods and techniques to use in teaching. It was seen that some pre-service teachers did not specify the knowledge and characteristics of the country.

\section{Conclusion and Suggestion}

In this study, which was conducted in order to determine the pedagogical content knowledge of teacher candidates' oriented instructional strategies in teaching Turkish as a foreign language, it was concluded that teacher candidates were not very hard in the questions about teaching methods, techniques and student errors, but they were found to be difficult in the applications aimed at eliminating student errors. Teaching Turkish as a Foreign Language Instructional Strategies Knowledge Test is prepared and practiced first time in teaching Turkish as a foreign language field for teacher candidates. It is prepared according to Bloom's classification that comprehension and application step of pre-service teachers.

Prospective teachers were lacking in identifying the reasons for the errors while providing satisfactory answers in using the teaching techniques to detect student errors and correct the error.

Almost all of the teacher candidates showed that they knew many teaching methods and techniques and showed that they could use them in appropriate situations. This feature shows that teacher candidates are successful in terms of instructional strategies.

When we look at the teaching methods and techniques used by pre-service teachers, drama, demonstration, creative writing, role playing and station technique come to the fore. Candidates were determined to prefer instructional strategies that would provide more up-to-date, lasting and more effective learning than classical presentation strategy and narrative technique.

As it is understood from the answers of the teacher candidates' knowledge test, it is seen that they are successful in terms of both content knowledge and pedagogical knowledge.

The failure of prospective teachers in identifying the causes of errors is due to the deficiencies in the grammar of Turkish. This deficiency is due to the fact that both sound, shapes, sentence and semantics courses are limited to one semester at the undergraduate level and that the lessons are learned in the form of memorizing the Turkish grammar rules and structures. If a teaching is carried out to understand the logic of rules and structures, the reasons for the errors will be more easily understood and it is thought that it will facilitate the teaching of Turkish as a foreign language with the right strategies.

Finally, this study is a study on instructional strategies in teaching Turkish as a foreign language as well as different and varied studies can be done about pedagogical content knowledge.

\section{REFERENCES}

[1] Y. Özden, Öğrenme ve ögretme (10. Baskl). Pegem Akademi, Ankara, 2011.

[2] C. Kavcar, (). Cumhuriyet döneminde dal öğretmeni yetiştirme. Ankara Üniversitesi Eğitim Bilimleri Fakültesi Dergisi, 32(1-2), 2002

[3] B. Acat, Z. Balbağ, B. Demir, A. Görgülü, Fen edebiyat 
fakültesi, eğitim fakültesi ve tezsiz yüksek lisans programına devam eden öğrencilerin öğretmenlik meslek algiları. Buca Eğitim Fakültesi Dergisi, (17), 2010.

[4] İ. Yıldırım, (Ĕgitim psikolojisi (1. Baskı). Anı Yayıncılık, Ankara, 2008.

[5] S. Magnusson, J. Krajcik, H. Borko, Nature, sources, and development of PCK for science teaching (pp. 95-120). In J. Gess-Newsome \& N.G. Lederman (eds.) Examining PCK: The construct and its implications for science education. Boston: Kluwer Academic Press, 1999.

[6] L. S. Shulman, Those who understand: knowledge growth in teaching, Educational Researcher, 15, 2, 4-14,1986.

[7] K. F. Cochran, DeRuiter, R. A. J.A. King, Pedagogical content knowing: an integrative model for teacher preparation. Journal of Teacher Education, 44(4),263-272, 1993.

[8] S. Gudmundsdottir, Pedagogical content knowledge: teachers' ways of knowing. East Lansing, MI: National Center for Research on Teacher Learning. (ERIC Document Reproduction Service No. ED290701), 1987.

[9] M. Z. Hashweh, Teacher Pedagogical Constructions: A Reconfiguration of Pedagogical Content Knowledge, Teachers and Teaching: Theory and Practice, 11:3, 273-292, 2005.

[10] T. De Jong, M.G. Ferguson-Hessler, Types and Qualitie of Knowledge, Educational Psychologist, 31(2), 105-113, 1996.

[11] J. Barnett, D. Hudson, Pedegogical context knowledge: toward a fuller understanding of what good science teachers know, Science Teacher Education, 85:426-453, 2000.

[12] H. E. Fischer, A. Borowski, O. Tepner, Professional Knowledge of Science Teachers, B.J. Fraser Et Al. (Eds.), Second International Handbook of Science Education, 437, Springer International Handbooks of Education 24, DOI 10.1007/978-1-4020-9041-7 30, C Springer Science+Business Media B. $\bar{V}, 2012$.

[13] D. J. Clandinin, F. M. Connelly, Teachers' Professional Knowledge Landscapes. New York: Teachers College Press, 1995.

[14] J. Loughran, P. Mulhall, A. Berry, In search of pedagogical content knowledge in science: developing ways, of articulating and documenting professional practice, Journal of Research in Sclence Teaching, Vol. 41, No. 4, 370-391, 2004.

[15] P. Mishra, M. J. Koehler, Technological Pedagogical Content Knowledge: A Framework for Teacher Knowledge, Teachers College Record, Volume 108, Number 6, 1017-1054, 2006.

[16] J. H. Van Driel, N. Verloop, W. De Vos, Developing Science Teachers 'Pedagogical Content Knowledge, Journal of Research in Sclence Teaching, Vol. 35, No. 6, 673-695, 1998.

[17] V. Kind, Pedagogical content knowledge in science education: potential and perspectives for progress. Studies in Science Education, 45: 169-204, 2009.

[18] Z. Batur, S. Balcı, Türkçe öğretmen adaylarının pedagojik alan bilgilerinin incelenmesi. Advyaman Üniversitesi Sosyal Bilimler Enstitüsü Dergisi, 6(11), 21-43, 2013.

[19] N. Karasar, Bilimsel araştırma yöntemi, Nobel yayınları, Ankara, 2012.

i This article is an extended version of oral presentation which was presented at $6^{\text {th }}$ International Congress on Social Science China to Adriatic, Ankara, (March 29-31, 2018). 